ISSN $1989-9572$

DOI: 10.47750/jett.2021.12.01.004

\title{
Investigation of articles on leadership and school management in turkey
}

Aycem Birand ${ }^{1}$

Dr. Cemre Günsel Haskasap ${ }^{2}$

Dr. Meryem Bastas ${ }^{3}$

\section{Journal for Educators, Teachers and Trainers, Vol. 12 (1)}

https://jett.labosfor.com/

Date of reception: 16 September 2020

Date of revision: 13 Dec 2020

Date of acceptance: 12 March 2021

Aycem Birand, Dr. Cemre Günsel Haskasap, Dr. Meryem Bastas(2021). Investigation of articles on leadership and school management in turkey. Journal for Educators, Teachers and Trainers, Vol. 12(1). $22-36$

\footnotetext{
${ }^{1}$ Msc. Near East University, Ataturk Faculty of Education, North Cyprus

${ }^{2,3}$ Assist.Prof. University of Kyrenia, Faculty of Marine, North Cyprus
} 


\title{
Investigation of articles on leadership and school management in turkey
}

Aycem Birand ${ }^{1}$, Dr. Cemre Günsel Haskasap ${ }^{2}$, Dr. Meryem Bastas ${ }^{3}$

${ }^{1}$ Msc. Near East University, Ataturk Faculty of Education, North Cyprus

${ }^{2,3}$ Assist.Prof. University of Kyrenia, Faculty of Marine, North Cyprus

Email ID: aycem_birand@hotmail.com, cemre.gunsel@kyrenia.edu.tr, meryem.bastas@kyrenia.edu.tr

\begin{abstract}
The aim of this qualitative study is to analyse the content of randomly selected articles on leadership and school management published in scientific journals in Turkey, and to determine the descriptive characteristics, main and sub-dimensions, and general trends of those articles. For this purpose, the "leadership" and "school management" directories were scanned in Google Academy. The samples comprised randomly selected 30 articles that were published between the years of 2015-2021. The content analysis of these 30 articles was based on main and sub-themes. The results revealed that when the main themes of articles about leadership were examined, the subject of pedagogical leadership, effective leadership and rotational leadership were discussed more than other articles. In addition, in the articles related to school management, it was observed that organizational silence and favouritism emerged. These main themes created some negative sub-themes, such as fear, anxiety, anxiety, and lack of confidence and alienation of staff. In that case, it was observed that teachers were also influenced by their self-sufficiency perceptions.
\end{abstract}

Keywords: Leadership, school management, content analysis, academic journals

\section{INTRODUCTION}

Leadership has been a subject of many studies throughout history and has not lost its importance until today. The Word "leadership" is derived from Latin Word called "Lira." Leadership refers to the orientation skills used by people to reach their goals. Too many descriptions are made for leadership. Leadership is described by affecting people physically, emotionally and mentally, making efforts to achieve what they want, and reaching the goal in cooperation with the least conflict. Leadership means passing through education to rebuild and improve oneself during the life course. Certain features make up the leadership. These features are vision, honesty, professional competence and determination (Arslanoğlu, 2016).

With regards to leadership, there are five different approaches to leadership. These are classic, behavioral, situational, interactive and transformational approaches. Since the classical approach and transactional approaches change slowly and they are not appropriate for the rapidly changing education, influencing, controlling and organizing the educated people towards the end of the 20th century, transformational leadership behavior has emerged and began to be examined. While parents were teaching their children not to go against the authority before the 20th century, by the 20th century, parents have started to teach their children to question the authority (Kahraman, 2018).

Leadership and management have become two concepts that are often confused. The manager is the employee who organizes, executes and controls the tasks assigned by their superiors. But the leader is the individual who has the power to influence the organization and guide by determining the target, mission and vision. Although it is not possible for each manager to be a leader, each manager must have leadership qualities. The leader is who makes people want to achieve the goal without coercing them, makes people believe they can, motivates them, and can influence others without using force (Oğuz, 2015; Reis \& Formosinho, 2020).

Management is the process by which two or more people come together to achieve a goal and use the planning, organization, directing and auditing functions effectively. The implementation of school management is school field limited usage of educational management. The limits of this field are specified based on the aims and 
structure of the school system. It is one of the tasks of school management to use the human and material resources in the school in the most efficient way in accordance with school themes. Each school has its own characteristics. The main components that play important roles in school management are school managers, teachers, students and school staff (Mirici, 2008; Yeşilmen, 2016).

The school management is responsible for determining the authority and responsibilities of the school administrator besides perpetuating the school under its aims. The school management has main Themes. These are to increase productivity, to ensure the satisfaction of Education staff, to protect school health, to make school useful to the environment, and to keep pace with innovations and changes. The school manager is the one who plays a role in the functioning of the school management (Badur, 2014).

This study aims to show that the most effective element that plays a role in school management is the school administrator and that the leader administrators in the modern education system have a great influence on school management. This research in Leadership and School Management in Turkey randomly selected articles from the last 7 years, studies of the defining characteristics of the main and sub-dimensions and overall trends reveal descriptive results and aims to shed light on future work. Thanks to the content analysis, It is hoped that this study will lead especially education researchers, and will save them from repetition and mess in their research.

\section{METHOD}

\section{Research Design}

In this qualitative research, the articles on leadership and school management in Google Scholar were analyzed based on content analysis according to certain criteria. Content analysis is the association and summarization and interpretation of the data obtained following the purpose. It refers to the fact that concepts and themes are brought together or categorized and arranged and interpreted in an understandable way by the reader through content analysis (Selçuk \& Palanc1, 2014).

\section{Samples}

In the study, the "leadership" and "school management" directories were scanned in Google Scholar. As a result of this screening the articles published between the years of 2015 and 2021, a total of 30 articles on leadership, and 15 on school management were randomly selected.

\section{Data Analysis}

The data obtained from the sample articles was analyzed using the content analysis method based on the determined main and sub-themes. The results are presented via tables.

\section{RESULTS}

Main and Sub Themes of Articles on Leadership

Table 1: Themes of the sample articles

\begin{tabular}{|l|ll|l|l|}
\hline Main Theme & \multicolumn{2}{|l|}{ Sub Themes } & Main Theme & Sub Themes \\
\hline Change & $\bullet$ & Planned Goal & Transformational Leader & $\bullet$ Effective communication \\
& $\bullet$ & Vision & & $\bullet$ Vision-Mission \\
& $\bullet$ & Leader & & $\bullet$ Motivating \\
& $\bullet$ & Innovation & & $\bullet$ Goal \\
& & & $\bullet$ Effectiveness-efficiency \\
\hline
\end{tabular}

(Ayık, A., Diş, O. \& Çelik, Z.; 2016)

When the data in Table 1 are examined, it is emphasized that the openness of schools to change, must include purposeful, planned and innovative actions and the leader needs to have a vision. Besides, to have transformational leadership roles, it is necessary for managers to have effective communication as well as mission and vision, motivate their employees, have a purpose, and be a leader that provides a productive environment.

Table 2: Themes of the sample articles

\begin{tabular}{|l|ll|l|l|}
\hline Main Theme & \multicolumn{2}{|l|}{ Sub Themes } & Main Theme & Sub Themes \\
\hline $\begin{array}{l}\text { Organizational } \\
\text { Commitment }\end{array}$ & $\bullet$ & Loyalty and attitude & Instructional \\
& $\bullet$ & Organizational interest & $\begin{array}{l}\text { Mission } \\
\text { management }\end{array}$ \\
\hline
\end{tabular}




\begin{tabular}{|c|c|c|}
\hline & $\begin{array}{l}\text { - Themes and values of the } \\
\text { organization } \\
\text { Participation in the task }\end{array}$ & $\begin{array}{ll}\text { - } & \text { Teaching supervision } \\
\text { - } & \text { Leading } \\
\text { - } & \text { Development } \\
\text { learning climate } & \text { of }\end{array}$ \\
\hline
\end{tabular}

(Yaman, E. \& Ezer, Ö; 2015)

With regards to the Main and Sub-Themes specified in Table 2, when it comes to the organizational commitment of teachers, the organization and attitude loyalty to the interests of the organization and the organization's goals and values, as well as participation in the mission of individuals is also important. It is emphasized that managers should have roles of mission holder, programming and teaching management, performing teaching supervision, leading and improving learning climate when the teachers ' educational leadership behaviours are considered.

Table 3: Themes of the sample articles

\begin{tabular}{|c|c|c|c|}
\hline Main Theme & Sub Themes & Main Theme & Sub Themes \\
\hline Educational leader & $\begin{array}{l}\text { - Defining the } \\
\text { purpose } \\
\text { - } \quad \text { Learning- } \\
\text { teaching process } \\
\text { teacher development } \\
\text { Teaching- } \\
\text { Climate Development } \\
\text { Instructional } \\
\text { teaching Supervision of }\end{array}$ & Academic Optimism & $\begin{array}{l}\text { - } \quad \text { Collective } \\
\text { competence } \\
\text { - } \quad \text { Trust(teacher- } \\
\text { parent-student) } \\
\text { - Academic } \\
\text { emphasis }\end{array}$ \\
\hline
\end{tabular}

(Yılmaz, E. \& Kurşun, A., T.; 2015).

In table 3, the aspects of educational leadership behaviours of managers are emphasized. It is stated that managers should have skills of defining Themes, cooperation and communication skills, performing learning and teaching process efficiently, improving teaching and teacher, and controlling teaching as well as improving teaching climate. When it comes to teacher's academic optimism, the trust environment is important. In addition, collective competence and academic emphasis constitute the Sub-Themes of academic optimism.

Table 4: Themes of the sample articles

\begin{tabular}{|c|c|c|c|}
\hline Main Theme & Sub Themes & Main Theme & Sub Themes \\
\hline Transformational leader & $\begin{array}{l}\text { - Vision-Mission } \\
\text { Conscience } \\
\text { - Motivating } \\
\text { - Innovative-Creative } \\
\text { - Supportive }\end{array}$ & $\begin{array}{l}\text { Organizational } \\
\text { Commitment }\end{array}$ & $\begin{array}{l}\text { - Job satisfaction } \\
\text { - Participation in Management } \\
\text { - } \text { Communication } \\
\text { - } \text { Trust } \\
\text { - Motivation } \\
\text { - Efficiency }\end{array}$ \\
\hline
\end{tabular}

(Demirtaş, E. \& Şama, E.; 2016).

In Table 4, according to Main and Sub-Themes, it is obvious that transformation leaders in schools need innovative, creative and supportive individuals who have vision and mission awareness. However, it is emphasized that in order to have an organizational commitment in schools, it is necessary to have a high level of participation in management and an environment that is open to communication, reliable, motivated and effective.

Table 5: Themes of the sample articles

\begin{tabular}{|c|c|c|c|}
\hline Main Theme & Sub Themes & Main Theme & Sub Themes \\
\hline Leadership of Teacher & $\begin{array}{ll}- & \text { Effective } \\
\text { Communication } \\
- & \text { Leading } \\
- & \text { Creative } \\
- & \text { Cooperation }\end{array}$ & Learner autonomy & $\begin{array}{l} \\
\text { - Active participation } \\
\text { in learning } \\
-\quad \quad \text { Self-evaluation } \\
\text { - Independent } \\
\text { thinking }\end{array}$ \\
\hline
\end{tabular}




\begin{tabular}{|l|l|l|l|}
\hline & $\bullet \quad$ Guidance & & $\begin{array}{l}\bullet \\
\bullet\end{array}$ \\
& & Guidance \\
\hline
\end{tabular}

(Yılmaz, K., Oğuz, A. \& Altınkurt, Y.; 2016).

In table 5., the realization of behaviours such as effectively communicating, leading, being creative and cooperative and guidance in the leadership of teacher have come forward. Furthermore, effective participation in learning, self-assessment, independent thinking, internal motivation and guidance are required in order to support learner autonomy.

Table 6: Themes of the sample articles

\begin{tabular}{|c|c|c|c|}
\hline Main Theme & Sub Themes & Main Theme & Sub Themes \\
\hline School Effectiveness & $\begin{array}{l}\text { - Vision } \\
\text { - Aim and Goal } \\
\text { - Effective } \\
\text { - Communication } \\
\text { - Physical } \\
\text { Environment } \\
\text { - Material } \\
\text { - Spirit } \\
\text { - Staff }\end{array}$ & Effective Leadership & $\begin{array}{ll}- & \text { Directive } \\
\text { - } & \text { Plan } \\
\text { - } & \text { Vision } \\
\text { - } & \text { Influence } \\
\text { - } & \text { Motivator/incentive } \\
\text { - } & \text { Cooperative }\end{array}$ \\
\hline
\end{tabular}

(Cerit, Y. \& Yıldırım, B.; 2017).

Table 6 highlights the need for managers to have a personality that knows the vision, aims and Themes of the managers, has effective communication, knows the physical environment, materials and personnel of the school and can give morale when looking at the effectiveness of the managers. However, managers need to have the role of directing, planning, visionary, effective, motivating (incentive) and collaborating roles to become an effective leader.

Table 7. Themes of the sample articles

\begin{tabular}{|c|c|c|c|}
\hline Main Theme & Sub Themes & Main Theme & Sub Themes \\
\hline Performance of Teacher & $\begin{array}{l}\text { - Contribution to goal } \\
\text { - Organizational } \\
\text { Behavior } \\
\text { - Work Experience } \\
\text { - Personality Traits } \\
\text { - Job satisfaction } \\
\text { - Organizational } \\
\text { Commitment }\end{array}$ & Job Satisfaction & $\begin{array}{l}\text { - } \\
\text { - } \\
\text { satisfaction } \\
\text { - } \\
\text { - }\end{array}$ \\
\hline
\end{tabular}

(Özdemir, M. \& Yirmibeş, A.; 2016).

In table 7 , themes such as contribution to goal, organizational behavior, work experience, personality traits, job satisfaction and organizational commitment are emphasized as sub-themes that affect the performance of a teacher. Positive attitude in the organization, needs satisfaction, appreciation, and performance such as behaviours are prominent to achieve job satisfaction.

Table 8: Themes of the sample articles

\begin{tabular}{|l|ll|}
\hline Main Theme & Sub Themes \\
\hline Effective Leadership & $\bullet$ & Effective Communication \\
& $\bullet$ & Democratic-Tolerance \\
& $\bullet$ & Excited \\
& $\bullet$ & Vision Owner \\
& $\bullet$ & Trustworthy \\
& $\bullet$ & Positive \\
\hline
\end{tabular}


(Özmantar, Z. K. \& Çetin, Y. Ç.; 2017).

Table 8 shows that to be effective leaders; school principals must have roles of acting behaviours that exemplify effective communication, democratic and tolerant attitude, excitement, vision, trustworthiness and positiveness.

Table 9: Themes of the sample articles

\begin{tabular}{|l|ll|}
\hline Main Theme & \multicolumn{2}{|l|}{ Sub Themes } \\
\hline Technological & $\bullet$ & Education technology \\
Leadership & $\bullet$ & Information / Digital Age \\
& $\bullet$ & Professional development \\
\hline
\end{tabular}

(Görgülü, D. \& Küçükali, R.; 2018).

In Table 9, it is emphasized that administrators with technological leadership in schools should have information about educational technology, have a personality that can keep up with the information / digital age and develop themselves professionally under today's conditions.

Table 10: Themes of the sample articles

(Şahin, Ç. Ç., Avcı, Y. E. \& Anık, S.; 2020)

\begin{tabular}{|l|ll|}
\hline Main Theme & \multicolumn{2}{|l|}{ Sub Themes } \\
\hline Digital Leadership & $\bullet$ & Technology \\
& $\bullet$ & e-leadership \\
& $\bullet$ & Use of tools \\
& $\bullet$ & Change \\
\hline
\end{tabular}

When Table 10 is examined, it is deemed important that people have knowledge of technology and have access to experience that and also use technological tools to achieve digital leadership. Moreover, it is emphasized that there should be a willingness to be open to change and to be an e-leader.

Table 11: Themes of the sample articles

\begin{tabular}{|l|l|l|l|}
\hline Main Theme & Sub Themes & Main Theme & Sub Themes \\
\hline Toxic & $\bullet$ Insignificance & School Climate & $\bullet$ Democratic \\
Leadership & - Sordidness & & $\bullet$ Man to school \\
& - Selfishness & & $\bullet$ Leadership and interaction \\
& $\begin{array}{l}\text { - Negative mood } \\
\text { - Bullying, rude, destructive } \\
\text { behavior }\end{array}$ & & $\bullet$ Success factor \\
& & & $\bullet$ Conflict \\
\hline
\end{tabular}

(Tepe, N. \& Y1lmaz, G.; 2020)

When we look at Table 11, the insignificant nature of the toxic leader, selfishness and destructive behavior, selfishness, bullying and rude behaviours push the employees to a negative mood. It is seen that by creating a positive school climate, democratic environment, acting sincerely, and conflicts can be managed and success can be achieved by healthy interaction with the leader. A positive school climate is not sought in a school environment with a toxic leader.

Table 12: Themes of the sample articles

\begin{tabular}{|l|ll|l|ll|}
\hline Main Theme & \multicolumn{2}{|l|}{ Sub Themes } & Main Theme & \multicolumn{2}{l|}{ Sub Themes } \\
\hline Course Supervision & $\bullet$ & Effectiveness & Instructional & $\bullet$ & Vision \\
& $\bullet$ & Productivity & Leadership & $\bullet$ & Motivation \\
& $\bullet$ & Control & & $\bullet$ & Supporting \\
& $\bullet$ & Guidance & & $\bullet$ & Problem-solving \\
& $\bullet$ & Order & & - & Ability to manage \\
& & & & conflict & \\
\hline
\end{tabular}

(Koşar, S. \& Buran, K.; 2019).

As can be seen in Table 12, effectiveness and efficiency can be seen in the school environment and order can be created thanks to the lesson control. By controlling, teachers can also be guided on missing and wrong matters. 
The essential features of an instructional leader are to have a vision, to motivate and support the employee, and to direct the conflict in a possible situation by solving the problems that arise.

Table 13. Themes of the sample articles

\begin{tabular}{|l|ll|l|l|}
\hline Main Theme & \multicolumn{2}{|l|}{ Sub Themes } & Main Theme & Sub Themes \\
\hline Ethical & $\bullet$ & Moral awareness & Organizational & $\bullet$ Insecurity \\
Leadership & $\bullet$ & Motivating & Cynicism & $\bullet$ Disdain \\
& $\bullet$ & Fair & & $\bullet$ Negative role attitude \\
& $\bullet$ & Lens & & $\bullet$ Not taking responsibility \\
& $\bullet$ & Value & & $\bullet$ No effort \\
\hline
\end{tabular}

(Zengin, T. \& Arpac1, Ö.; 2021)

The article in Table 13 includes two Main Themes as the ethical leader and organizational cynicism. In the study, the ethical leader states that they are people with high moral awareness, motivate their employees, create a fair working environment, approach events objectively and give importance to values. It is emphasized that in organizational cynicism, there is insecurity and disdain in the working environment, negative role attitudes are shown, there is no sense of responsibility and no effort is made in the organization.

Table 14: Themes of the sample articles

\begin{tabular}{|c|c|c|c|}
\hline Main Theme & Sub Themes & Main Theme & Sub Themes \\
\hline Leadership Styles & $\begin{array}{l}\text { Transformational } \\
\text { (supportive, creative, achievable, } \\
\text { vision) } \\
\text { - } \quad \text { Sustainer } \\
\text { (target, result tracking, control) } \\
\text { (not taking responsibility, not being able } \\
\text { to make a decision, passive, ineffective) }\end{array}$ & $\begin{array}{l}\text { School } \\
\text { Effectiveness }\end{array}$ & $\begin{array}{lc}- & \text { Goal-goal } \\
\bullet & \text { Innovator } \\
\text { - } & \text { The problem- } \\
\text { solving school } \\
\text { - } \\
\text { Lead manager }\end{array}$ \\
\hline
\end{tabular}

(Ermedyan, M. \& Can, N.; 2020).

In Table 14, three sub-themes are mentioned in leadership styles. One of them is the transformational leader, the individuals who support the employees of this leader, are creative, have a vision and make an effort to reach the goal. Another leadership is the sustaining leader. This type of leader aims to achieve the goal. He monitors the results and thinks to reach his goal with the control mechanism. Finally, the liberating leader refers to the passive and ineffective leader who refuses to take responsibility and cannot decide on his own. Another main theme of the article is school effectiveness. To ensure school effectiveness, it is emphasized that there must be a good leader administrator. While this leader has goals and objectives, he should also have a personality open to innovation. It should also be able to solve any problem that arises.

Table 15: Themes of the sample articles

\begin{tabular}{|l|l|l|l|l|l|}
\hline Main Theme & Sub Themes & Main Theme & Sub Themes & Main Theme & Sub Themes \\
\hline Authentic & Confidence & Organizational & Volunteering & Organizational & Emotional \\
Leadership & Sincerity & Citizenship & Sacrifice & & \\
& Faith - Value & & Owning & & closeness \\
& & & & & Believer \\
& & & & & \\
& & & & & \\
& & & & & \\
\hline
\end{tabular}

(Gökyer, N. \& Koçak, O.; 2020).

As seen in Table 15, there are three Main Themes. Authentic leaders are managers, who trust their employees, are sincere and have faith and values. The concept of organizational citizenship, the second main theme, is based on volunteering and sacrifice in the work environment. It is also important to be able to own the organization. And the last major theme is organizational commitment. There is emotional intimacy in organizational commitment. Besides, being faithful in the organization, volunteering and internality are among the important concepts.

Main and Sub Themes of Articles on School Management 
Table 16: Themes of the sample articles

\begin{tabular}{|l|ll|}
\hline Main Theme & Sub Themes \\
\hline Safe School & $\bullet$ & School building \\
& $\bullet$ & School population \\
& $\bullet \quad$ School environment \\
& $\bullet$ & Cooperation (school principal-organization) \\
\hline
\end{tabular}

(Karakütük, K., Özbal, E., Ö. \& Sağlam, A.; 2017)

In Table 16, it is observed that sub themes such as the school building, the population of the school, the school environment, the cooperation of the school personnel and the school manager stand out when it is said "safe school",

Table 17: Themes of the sample articles

\begin{tabular}{|l|l|l|l|l|l|}
\hline Main Theme & Sub Themes & Main Theme & Sub Themes & Main Theme & Sub Themes \\
\hline Teacher Self- & Self-belief & Favouritism & Anti- & Organizational & Unfair practice \\
Sufficiency & Performance & & discrimination & silence & Fear \\
Perception & A sense of & & Supporting/ & & Concern/worry \\
& responsibility & & Protection & & Lack of Trust \\
& & Control anxiety & & Reaction \\
& & & Alienation & & \\
\hline
\end{tabular}

(Aydin, Y.; 2016)

Table 17 shows that organizational silence is prominent in environments caused by unfair practice, fear, concern, worry, lack of trust and reaction. Besides, exhibition behaviours such as anti-discrimination, protection, and support, and emerging of control anxiety and alienations show that favouritism in the organization is realized. In order to achieve teacher self-efficacy perception, the teacher needs to have self-confidence, an environment in which the person can demonstrate his performance, and an awareness of responsibility.

Table 18: Themes of the sample articles

\begin{tabular}{|l|ll|l|l|}
\hline Main Theme & \multicolumn{2}{|l|}{ Sub Themes } & Main Theme & Sub Themes \\
\hline Management & $\bullet$ & Job satisfaction & Job Satisfaction & $\bullet$ Payment \\
Format & $\bullet$ & Organizational efficiency & & $\bullet$ Environment \\
& $\bullet$ & Motivation / efficiency & & $\bullet$ Audit \\
& $\bullet$ & School climate and culture & & $\bullet$ Subordinate \\
& $\bullet$ & Organizational commitment & & relationship \\
\hline
\end{tabular}

(Başaran, M. \& Güçlü, N.; 2018).

Table 18 shows the sub-themes that shape the management style. The job satisfaction, productivity, motivation, commitment, climate and culture of the employees in an organization show the management style of the organization. To achieve job satisfaction, the method of payment, the working environment, the supervision applied and the subordinate-superior relationship are important. The few and many of these sub-themes show whether the employees have job satisfaction.

Table 19: Themes of the sample articles

\begin{tabular}{|l|l|l|l|}
\hline Main Theme & Sub Themes & Main Theme & Sub Themes \\
\hline Nepotism & $\bullet$ Self-interest & Organizational & $\bullet$ Penalty / reward / promotion / wage criteria \\
& $\begin{array}{l}\text { Deviation } \\
\text { right/justice } \\
\text { - Benefit }\end{array}$ & Justice & $\begin{array}{l}\bullet \text { Fair practices } \\
\text { Contact } \\
\end{array}$ \\
\hline
\end{tabular}

(Cesur, A. \& Erol, E.; 2020).

When we look at Table 19, it is seen that the existence of clientelism in an organization depends on personal interests. In an environment of nepotism, deviations in rights and justice are seen and interest is involved. Organizational justice is not sought in these organizations. In environments where there is organizational justice, 
criteria for concepts such as punishment, reward, promotion and wage are determined. Fair practices are applied to employees and a healthy climate is observed.

Table 20: Themes of the sample articles

\begin{tabular}{|l|l|l|l|}
\hline Main Theme & Sub Themes & Main Theme & Sub Themes \\
\hline Skills for & $\bullet$ Individual attitude/behavior & Intimidation & $\bullet$ Insecurity \\
Managing & $\bullet$ Value / norms & & $\bullet$ Communication format \\
Diversity & $\begin{array}{l}\text { - Managerial practice } \\
\text { - Policy }\end{array}$ & $\begin{array}{l}\text { - Hierarchical structure stiffness / flexibility } \\
\text { - Management style }\end{array}$ \\
\hline
\end{tabular}

(Özdoğru, M.;2020).

Table 20 includes two Main Themes. The first Main Theme is the skills of managing awareness, and individual attitudes or behaviours have an important place in managing differences in the organization. In addition, it is important to act according to the values / norms determined by the organization or the manager, to include managerial practices and to act with the policies of the organization in terms of managing differences. The second Main Theme is mobbing, stems from the insecurity of the environment in the organization and the rigidity or flexibility of the hierarchical structure. The communication style and management style in the organization states that it causes mobbing the employees.

Table 21: Themes of the sample articles

\begin{tabular}{|l|l|l|l|}
\hline Main Theme & Sub Themes & Main Theme & Sub Themes \\
\hline \multirow{3}{*}{ Management } & $\bullet$ Resource usage & School Climate & $\bullet$ Mode of administration \\
Skills & $\bullet$ Contact & & $\bullet$ Motivation management \\
& $\bullet$ Decision making & & $\bullet$ Contact \\
& $\bullet$ Managerial behavior & & $\bullet$ Organizational structure \\
\hline
\end{tabular}

(Altuntaş, B., Demirdağ, S. \& Ertem, H. Y.; 2020).

When Table 21 is examined, management skills consist of resource use, soundness of communication, decisionmaking mechanism and managerial behavior effectiveness. The better these sub-themes are managed, the stronger and more beneficial management skills are for the organization. In addition, it is important for the school climate to have a healthy management style, to give motivation to employees at the right rate, to have healthy communication, to have strong relationships and a solid organizational structure. The fact that these sub-themes take place in the organization healthily and strongly shows that the climate is also healthy. The climate of a school with well-managed management skills is also strong.

Table 22: Themes of the sample articles

(Coşgungönül, S. \& Gül, İ.; 2020)

\begin{tabular}{|l|ll|}
\hline Main Theme & \multicolumn{2}{|l|}{ Sub Themes } \\
\hline Democracy & $\bullet$ & Respect for thought \\
(Democratic attitudes and & $\bullet$ & Equal / Neutral \\
behaviours) & $\bullet$ & Free environment \\
& $\bullet$ & Fair / tolerance / cooperation \\
& $\bullet$ & Democratic election \\
& $\bullet$ & Contact \\
\hline
\end{tabular}

Table 22 mentions the importance of democracy in the organization. The organizations that display democratic attitudes and behavior are respected, creating an equal, impartial and free environment. Also, communication is bidirectional and healthy while democratic elections are held, and a fair, tolerant and cooperative environment is introduced.

Table 23: Themes of the sample articles

\begin{tabular}{|lr|ll|}
\hline Main Theme & \multicolumn{2}{|l|}{ Sub Themes } \\
\hline Participation & in & $\bullet$ & Rules and professional studies \\
Management & & $\bullet$ & Decision-making process \\
\hline
\end{tabular}




\begin{tabular}{|l|ll|}
\hline (Classroom Teachers) & $\bullet$ & Clan meetings \\
& $\bullet$ & School-parent association meetings \\
\hline
\end{tabular}

(Can, E. \& Ozan, C.; 2020).

In Table 23, the participation of classroom teachers in management is examined. It is important to participate in the decision-making process in determining the rules in schools and professional studies. In addition, it is thought that teachers' participation in group meetings and school-family association meetings made a great contribution to school management.

Table 24: Themes of the sample articles

\begin{tabular}{|l|ll|l|ll|}
\hline Main Theme & \multicolumn{2}{|l|}{ Sub Themes } & Main Theme & \multicolumn{2}{l|}{ Sub Themes } \\
\hline Management Process & $\bullet$ & Decision & Organizational & $\bullet$ & Manager behavior \\
Effectiveness & $\bullet$ & Planning & Justice & $\bullet$ & Fair decision \\
& $\bullet$ & Organizing & & $\bullet$ & Equality \\
& $\bullet$ & Contact & & Policy \\
& - & Influencing & & Consistency \\
& - & Coordination & & & \\
& - & Evaluation & & & \\
\hline
\end{tabular}

(Yıldırım, A. \& Açıl, Y.; 2020).

When we look at Table 24, it is seen that it is important to carry out the sub-steps such as decision making, planning, organizing, communication, influencing, coordination and evaluation in a healthy way for the management processes to progress effectively. It is stated that if a problem occurs in one of these steps, this process does not progress successfully and there may be problems in the management of the organization. Managerial behavior is considered important in environments with organizational justice. It can be said that organizational justice is achieved in environments where fair decisions are taken, also equality policy and consistency are observed.

Table 25: Themes of the sample articles

\begin{tabular}{|ll|ll|}
\hline Main Theme & \multicolumn{2}{|l|}{ Sub Themes } \\
\hline Experienced & in & $\bullet$ & Financial insufficiency \\
Management & & $\bullet$ & Lack of staff \\
Difficulties & $\bullet$ & Negative attitude \\
\hline
\end{tabular}

(Yıldız, C. D.; 2018).

In Table 25, difficulties experienced by managers in management are examined. Especially financial inadequacy, lack of personnel and negative attitudes experienced in the organization create difficulties in management and cause problems in the organization.

Table 26: Themes of the sample articles

\begin{tabular}{|l|ll|}
\hline Main Theme & \multicolumn{2}{|l|}{ Sub Themes } \\
\hline School Management & $\bullet$ & Don't take action \\
During the Pandemic & $\bullet$ & Duty and responsibility \\
Process & $\bullet$ & Problems (possibilities and decisions) \\
\hline
\end{tabular}

(Kavrayıc1, C. \& Kesim, E.; 2021).

In the article in Table 26, the extra duties and responsibilities of principals in the school administration during the pandemic process have occurred. Taking more precautions and dealing with problems has had an important place for them to manage this process successfully. Since the decisions made will affect the whole school and the staff, it is important to evaluate the facilities well and to fulfill the duties successfully.

Table 27: Themes of the sample articles

\begin{tabular}{|l|ll|}
\hline Main Theme & \multicolumn{2}{|l|}{ Sub Themes } \\
\hline School Management & $\bullet$ & Process-oriented qualifications \\
Experiences & $\bullet$ & Coordinating \\
\hline
\end{tabular}




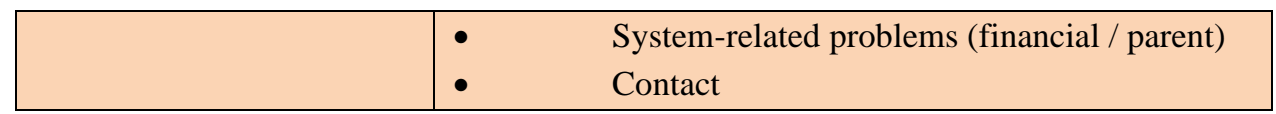

(Güneș, A. M. \& Esmer, B.; 2018).

When Table 27 is looked at, it is known that each administrator has their own experience in school management. For these experiences to turn into a successful process, managers need to work in a process-oriented manner, coordinate their employees, accurately solve system-related problems and ensure communication. In cases of system-related problems, the sufficient financial support of the school and the ability to work in cooperation with parents help to overcome this process as expected.

Table 28: Themes of the sample articles

\begin{tabular}{|l|ll|}
\hline Main Theme & \multicolumn{2}{|l|}{ Sub Themes } \\
\hline Teacher Effect in School & $\bullet$ & Gender \\
Management & $\bullet$ & Age \\
& $\bullet$ & Seniority \\
& $\bullet$ & Family structure \\
& $\bullet$ & Materiality \\
& $\bullet$ & Personality \\
\hline
\end{tabular}

(Güneş, A. M.; 2020).

Table 28 discusses the effect of teachers on school management. It has been revealed that the age, gender, seniority, family structure, materiality and personality of the teacher affect the school administration.

Table 29: Themes of the sample articles

\begin{tabular}{|l|ll|}
\hline Main Theme & \multicolumn{2}{|l|}{ Sub Themes } \\
\hline Participation in School & $\bullet$ & Decision making \\
Management & $\bullet$ & Problem-solving \\
(Counselor Teachers) & $\bullet$ & Cooperation \\
& $\bullet$ & Information exchange \\
\hline
\end{tabular}

(Can, E. \& Nikolayidis, U.; 2020).

When we look at Table 29, it is concluded that the participation of counsellor teachers in school administration is important. It has been revealed that especially counsellors should participate in the decision-making process, they can solve problems in any problem, cooperate with both families and colleagues and exchange information much contribute to the school administration.

Table 30: Themes of the sample articles

\begin{tabular}{|c|c|}
\hline Main Theme & Sub Themes \\
\hline $\begin{array}{l}\text { Participation in School } \\
\text { Management } \\
\text { (Guardian) }\end{array}$ & $\begin{array}{ll}- & \text { Parenthood } \\
- & \text { Contact } \\
- & \text { Volunteering } \\
- & \text { Learning at home } \\
- & \text { To decide } \\
- & \text { Cooperation with the community }\end{array}$ \\
\hline
\end{tabular}

(Çuhadar, A. İ.; 2020).

As seen in Table 30, the parents' contribution to the school administration has been examined. It is emphasized that the parents who participate in the school administration will understand the concept of parenthood better and that they participate in the decision-making process based on volunteerism in communication with the school. It is considered important to be able to continue the learning that takes place in the school at home, in cooperation with the parent-teacher. Besides, parents who contribute to the school management cooperate with society.

\section{DISCUSSION, CONCLUSION AND SUGGESTIONS}

As a result of the review of articles on leadership and school management between 2015 and 2021, 30 randomly selected articles have been examined according to their main and sub Themes. When the main themes of the articles on leadership are examined, it is seen that the subject of instructional leadership, effective leadership, and 
transformational leadership are discussed more than other articles, while organizational commitment, organizational commitment, change, teacher leadership, learner autonomy, academic optimism, school effectiveness, job satisfaction, technological leadership, digital leadership, toxic leadership, authentic leadership and teacher performance. When the articles are examined, it is emphasized in the articles that to have a transformational leader, leaders must have good communication, but have a vision and mission, a role that can motivate, improve efficiency and have a purpose. Also, in instructional leadership, a transformational leader should have a vision and mission, as well as the ability to change the learning climate, improve teaching and teacher, have the power to supervise, and know the program and teaching methods. Effective leadership, on the other hand, should have visionary, directing, motivating, cooperative, democratic and tolerant, positive characteristics. Looking at leadership, sub-goals such as vision, mission, motivation, communication and cooperation meet at a common point. The style of leadership seems to affect other main themes as well. It is observed that it affects the organizational (school) climate negatively, especially in environments with toxic leadership. The reason is that the toxic leader causes his employees to experience negative mental states and exhibits behaviours such as bullying and selfishness. Kaya, Göncü and Erarslan (2021) investigated the effects of managers' toxic leadership behaviours on organizational cynicism and employee silence. In the research, a significant relationship was found between these concepts. Furthermore, it has been revealed that these concepts constitute a major obstacle to the success of the employees.

When we look at the articles on leadership, it is seen that commitment to the organization is also examined, and the importance of job satisfaction, participation in management, communication, trust motivation and organizational interest are among the features that organizational commitment should have. With the 21 st century being a technological age, new concepts related to leadership have started to emerge. Especially digital leadership and technological leadership have been two separate concepts that are new subjects for research. It is emphasized that the common points of digital leadership and technological leadership are that managers need to know educational technology well and have the knowledge to use technological tools. For this, it has been proven by research that managers need professional development on these issues. With the emergence of training and leadership during the information age instead of traditional education, it has become an important requirement to inform managers and employees about this issue. Öz (2019) examined the character traits and competencies of school leaders in the digital world. As a result of the study, it was revealed that leadership styles have changed and transformed with the changing era, and digital leaders should have competencies such as technology literacy, knowledge of the subject, digital data creation, security and problem-solving.

When the articles on school management are examined, the building of the school, its surroundings and population constitute the most important sub-objectives of a safe school. But organizational silence and favouritism are also seen to emerge. These main themes that emerge in school management lead to negative sub-goals of the staff such as fear, anxiety, anxiety, lack of trust and alienation. In this case, it affects teachers' self-efficacy perceptions. Besides, studies show that management styles, styles, or skills affect the school climate, job satisfaction and organizational justice both positively and negatively. On the other hand, participation in school management has great importance in researches and it is seen that it affects the decisions taken, communication and cooperation. It has been proven that the participation of teachers and parents in the management gives positive results in the decisions taken.

Due to the recent pandemic, new studies on school management have also started. In particular, the problems faced by the school administration during the pandemic process, and the effectiveness of the decisions and measures taken have begun to be questioned. Sar1 and Nayır (2020) presented research on educational problems and opportunities during the pandemic period. At the end of the study, although there were problems in terms of education, it was seen that there were opportunities with these problems. In the field of education, it has been observed that there are problems with the process of learning and teaching, as well as problems with administrators and teachers. However, it has been shown with the study that it benefits the development of school management, parent participation and the development of learning and teaching skills.

There is not much research on democracy (democratic attitudes and behaviours), which is a new concept in school management. It is revealed that in schools and organizations where democracy exists, there is respect for thought, a free, equal and impartial environment is established, democratic elections are made and activities are carried out for cooperation and communication. Erdem and Eğmir (2020) aim to provide information about the importance of the relationship between democracy and education in their studies. As a result of the research, it has been 
revealed that a desired social environment can be created thanks to the formation of individual free environments, acceptance of individual differences and an educational environment where equally open approaches are formed together with democratic education.

As a result, the following suggestions can be listed in light of the findings obtained from the research.

1. Future studies can be conducted with a wider picture reflecting the development and change of leadership and school management research conducted in Turkey by examining more journals to cover a wider process.

2. Articles on effective leadership and school management in Turkey and abroad can be reviewed comparatively

3. Repeating similar research with 5-10-year intervals by comparing the results with previous research findings can contribute to the field

4. There are not many publications on themes like academic optimism and learner autonomy. New research on these issues can be done.

5. There is not much research on digital leadership and the technological leadership of educational administrators. Studies on this subject can be included.

\section{REFERENCES}

1. Altuntaş, B., Demirdağ, S. \& Ertem, H. Y. (2020). Investigation of the Relationship between

2. School Administrators 'Management Skills and School Climate According to Parents' Perceptions, Academia Educational Research Journal, 5(2), 254-269.

3. Arslanoğlu, Ş. (2016). Leadership in High School Principals, The Effect of Leadership Levels Teachers' Motivation (Konya City Example). Master's Thesis. KTO Karatay University Institute of Social Sciences, Konya.

4. Aydin, Y. (2016). The Relation of Organizational Silence to Nepotism in School Management and Teachers' Perception of Self-Efficacy, Educational Administration in Theory and Practice, 22(2), 165-192.

5. Ayık, A., Diş, O. \& Çelik, Z. (2016). The Relationship Between Transformational Leadership Roles of School Principals and Schools' Openness to Change, Kastamonu Journal of $\quad$ Education, 24(2), 547564.

6. Badur, S. (2014). Problems Encountered in School Management in 12-Year Compulsory Education System. Master Thesis. Zirve University Institute of Social Sciences, Gaziantep.

7. Başaran, M. \& Güçlü, N. (2018). Investigation of the Relationship Between School Administrators' Management Styles and Teachers' Job Satisfaction, Gazi University Journal of Gazi Education Faculty, 38(3), 949-963.

8. Can, E. \& Nikolayidis, U. (2020). Participation in School Management: A Study on Counselors, Anemon Muş Alparslan University Journal of Social Sciences, 8(6), $\quad 1787-\quad 1806$.

9. Can, E. \& Ozan, C. (2020). Investigation of Class Teachers' Participation in School Management, National Education, 49(225), 55-87.

10. Cerit, Y. \& Yıldırım, B. (2017). The Relationship between Effective Leadership Behaviors of Primary School Principals and School Effectiveness, Bartın University Journal of Education Faculty, 6(3), 902-914.

11. Cesur, A. \& Erol, E. (2020). The Relationship between Nepotism and Organizational Justice

in School Management: The Case of Afyonkarahisar Province, International Journal of Society Studies, 15(25).

12. Coşgungönül, S. \& Gül, İ. (2020). Primary School Teachers' Views on the Democracy of School Management. International Pegem Education Congress Proceedings (213- 221), Ankara. DOI $10.14527 / 9786257228992$.

13. Çuhadar, A. İ. (2020). Parents of School Management Participation by National Legislation in Turkey, YYÜ Journal of the Faculty of Education,17(1), 374-404.

14. Demirtaş, E. \& Şama, E. (2016). Transformational Leadership and Organizational Commitment Relationship in Schools, Iğdır University Journal of Social Sciences, 10, 275-298. 
15. Erdem, C. \& Eğmir, E. (2020). Democracy and Education: A Conceptual Review, Afyon Kocatepe University Journal of Social Sciences, 22 (100th Anniversary of the Turkish Grand National Assembly and Special Issue of National Will), 159-171.

16. Ermedyan, M. \& Can, N. (2020). The Relationship between School Administrators' Leadership Styles and School Effectiveness, Gaziantep University Journal of Educational Sciences, 4(2).

17. Gökyer, N. \& Koçak, O. (2020). The Relationship between Authentic Leadership Behaviors of School Administrators and Teachers' Organizational Citizenship Behaviors and Organizational Commitment Levels, (54), 381-414.

18. Görgülü, D. \& Küçükali, R. (2018). Investigation of Teachers' Technological Leadership Self-efficacy, Journal of International Leadership Studies: Theory and Practice, 1(1), 1-12.

19. Güneş, A. M. (2020). The Effect of Teachers on Primary School Principals' School Management, Gazi University Journal of Gazi Education Faculty, 40(1), 23-50.

20. Güneş, A. M. \& Esmer, B. (2018). The Experiences of Primary, Secondary and High School Principals in School Management Turkish Studies, 13(19), 843-864.

21. Kahraman, Z. Y. (2018). "Community Leaders Are Coming” The Effect of Leadership Training on Leadership Orientations of Teacher Candidates. Master Thesis. Abant İzzet Baysal University Institute of Educational Sciences, Bolu.

22. Karakütük, K., Özbal, E. Ö. \& Sağlam, A. (2017). Teachers 'and School Principals' Opinions Practices Made to Ensure School Safety in School Management, Mersin University Journal of Education Faculty, 13(3), 1214-1232.

23. Kavrayıc1, C. \& Kesim, E. (2021). School Management in the Covid-19 Pandemic Process: Educational Management in a Qualitative Research, Theory and Practice, 27(1), 1005- 1060.

24. Kaya, N., Göncü, F. T. \& Erarslan, İ. (2021). Effects of Toxic Leadership Behaviors of Managers on Organizational Cynicism and Employee Silence (A Research for the Public Sector), Journal of Life Economics, 8(1), 111-120.

25. Koşar, S. \& Buran, K. (2019). Examination of Course Supervision Activities of School Principals in the Context of Instructional Leadership, Journal of Qualitative Research in Education, 7(3), 1232-1265.

26. Mirici, İ. H. (2008). "Training EFL/ESL Teachers for a Peaceful Asia-Pacific Region"'. Asia Pacific Education Review. 9(3), 344-354.

27. Oğuz, A. (2015). Investigation of the Relationship Between Visionary Leadership Behavior and Instructional Leadership Behavior of Primary School Principals According to Teacher Perceptions (Batman Province Example). Master Thesis. Zirve University Institute of Social Sciences, Gaziantep.

28. Öz, Ö. (2019). Digital Leadership: Being a School Leader in the Digital World, International Journal of Leadership Studies: Theory and Practice, 3(1), 45-57.

29. Özdemir, M. \& Yirmibeș, A. (2016). The Mediating Effect of Job Satisfaction in the Relationship between Leadership Team Harmony and Teacher Performance in Schools, Gazi University Journal of Gazi Faculty of Education, 36(2), 323-348.

30. Özdoğru, M. (2020). The Relationship Between School Administrators' Skills of Managing Differences and Mobbing, Journal of New Approaches in Education, 3(2), 73-85.

31. Özmantar, Z. K. \& Çetin, Y. E. (2017). Investigation of Leadership Skills of School Principals Working in Primary Education Institutions, Mustafa Kemal University Journal of Social Sciences Institute, 14(37), 261-284.

32. Reis, C. S., Formosinho, M. (2020). The Sisyphic Destiny of Philosophy of Education. International Journal of Curriculum and Instruction, 12(Special Issue), 34-49.

33. Sarı, N. \& Nayır, F. (2020). Pandemic Education: Challenges and Opportunities, Turkish Studies, 15(4), 959-975

34. Şahin, Ç. Ç., Avcı, Y. E. \& Anık, S. (2020). An Investigation of Digital Leadership Perception Through Metaphors, Electronic Journal of Social Sciences, 19(73), 271- 286.

35. Tedmem, Z. S., Palanc1, M., Kandemir, M. \& Dündar, H. (2014). Trends of Researches $\quad$ Published $\quad$ in Education and Science Journal: Content Analysis, Education and Science, 39(173).

36. Tepe, N. \& Y1lmaz, G. (2020). Toxic Leadership Behaviors of School Administrators as a Predictor of Teachers' Perceptions of School Climate, International Journal of Society Studies, 15(25), 3360-3381. 
37. Yaman, E. \& Ezer, Ö. (2015). The Relationship Between the Instructional Leadership Behaviors of Middle School Principals and the Organizational Commitment of Teachers According to Teacher Perceptions, Journal of the Faculty of Education, Bayburt University, 10(1).

38. Yeşilmen, F. (2016). School Management, Organizational Communication and Examination of the Problems Arising from School Administrators and Teachers. Istanbul Aydın University Institute of Social Sciences, Istanbul

39. Yıldırım, A. \& Açıl, Y. (2020). The Relationship between the Effectiveness of Management Processes in School Management and Organizational Justice, International Journal of Karamanoğlu Mehmetbey Educational Research, 2(2), 169-179.

40. Yıldız, C. D. (2018). Evaluation of Difficulties in the Management of Preschool Education Institutions, Anemon Muş Alparslan University Journal of Social Sciences, 6(18), 95- 102.

41. Yılmaz, E. \& Kurşun, A. T. (2015). The Relationship between the Instructional Leadership Behaviors of School Principals and the Academic Optimism Levels of Teachers, Journal of Contemporary Management Sciences, 1(1).

42. Yılmaz, K., Oğuz, A. \& Altınkurt, Y. (2016). The Relationship Between Teachers' Leadership Behaviors and Their Behaviors Supporting Learner Autonomy, Hacettepe University Journal of Education.

43. Zengin, T. \& Arpac1, Ö. (2021). Investigation of the Effects of Ethical Leadership Traits of School Administrators on Organizational Cynicism According to Teacher Perceptions, Trakya Journal of Education, 11(1), 347-365. 